\title{
In vascular smooth muscle cells paricalcitol prevents phosphate-induced
}

\section{Wnt/ $\beta$-catenin activation}

\author{
Julio M. Martínez-Moreno, ${ }^{1}$ Juan R. Muñoz-Castañeda, ${ }^{1}$ Carmen Herencia, ${ }^{1}$ Addy Montes de Oca, ${ }^{2}$ \\ Jose C. Estepa, ${ }^{2}$ Rocio Canalejo, ${ }^{1}$ Maria E. Rodríguez-Ortiz, ${ }^{1}$ Pablo Perez-Martinez, ${ }^{3}$ \\ Escolástico Aguilera-Tejero, ${ }^{2}$ Antonio Canalejo, ${ }^{4}$ Mariano Rodríguez, ${ }^{1}$ and Yolanda Almadén ${ }^{3}$ \\ ${ }^{1}$ Servicio de Nefrologia, Red in Ren, Instituto Maimónides de Investigación Biomédica de Córdoba, (IMIBIC) Hospital \\ Universitario Reina Sofia, Cordoba, Spain; ${ }^{2}$ Department of Medicina y Cirugia Animal, Universidad de Cordoba, Cordoba, \\ Spain; ${ }^{3}$ Lipid and Atherosclerosis Unit, Instituto Maimónides de Investigación Biomédica de Córdoba (IMIBIC), Reina Sofia \\ University Hospital/University of Cordoba, and Centro de Investigación Biomédica en Red de la Fisiopatología de la \\ Obesidad y Nutrición (CIBERobn), Instituto de Salud Carlos III, Cordoba, Spain; and ${ }^{4}$ Department of Biologia Ambiental y \\ Salud Publica, Universidad de Huelva, Huelva, Spain
}

Submitted 20 December 2011; accepted in final form 2 August 2012

\begin{abstract}
Martínez-Moreno JM, Muñoz-Castañeda JR, Herencia C, Montes de Oca A, Estepa JC, Canalejo R, Rodríguez-Ortiz ME, Perez-Martinez P, Aguilera-Tejero E, Canalejo A, Rodríguez M, Almadén Y. In vascular smooth muscle cells paricalcitol prevents phosphate-induced Wnt/ $\beta$-catenin activation. Am J Physiol Renal Physiol 303: F1136-F1144, 2012. First published August 8, 2012; doi:10.1152/ajprenal.00684.2011.- The present study investigates the differential effect of two vitamin D receptor agonists, calcitriol and paricalcitol, on human aortic smooth muscle cells calcification in vitro. Human vascular smooth muscle cells were incubated in a high phosphate (HP) medium alone or supplemented with either calcitriol $10^{-8} \mathrm{M}(\mathrm{HP}+\mathrm{CTR})$ or paricalcitol $3 \cdot 10^{-8} \mathrm{M}(\mathrm{HP}+\mathrm{PC})$. HP medium induced calcification, which was associated with the upregulation of mRNA expression of osteogenic factors such as bone morphogenetic protein 2 (BMP2), Runx2/Cbfa1, Msx2, and osteocalcin. In these cells, activation of $\mathrm{Wnt} / \beta$-catenin signaling was evidenced by the translocation of $\beta$-catenin into the nucleus and the increase in the expression of direct target genes as cyclin D1, axin 2, and VCAN/versican. Addition of calcitriol to HP medium (HP + CTR) further increased calcification and also enhanced the expression of osteogenic factors together with a significant elevation of nuclear $\beta$-catenin levels and the expression of cyclin D1, axin 2, and VCAN. By contrast, the addition of paricalcitol $(\mathrm{HP}+\mathrm{PC})$ not only reduced calcification but also downregulated the expression of BMP2 and other osteoblastic phenotype markers as well as the levels of nuclear $\beta$-catenin and the expression of its target genes. The role of $\mathrm{Wnt} / \beta$ catenin on phosphate- and calcitriol-induced calcification was further demonstrated by the inhibition of calcification after addition of Dickkopf-related protein 1 (DKK-1), a specific natural antagonist of the Wnt/ $\beta$-catenin signaling pathway. In conclusion, the differential effect of calcitriol and paricalcitol on vascular calcification appears to be mediated by a distinct regulation of the BMP and Wnt/ $\beta$-catenin signaling pathways.
\end{abstract}

vascular calcification; calcitriol; paricalcitol; VSMCs; Wnt/ $\beta$-catenin

UREMIC PATIENTS FREQUENTLY present vascular calcifications (VC), which contributes to the high rate of cardiovascular morbidity and mortality observed in these patients (61). The generation of VC in uremic patients is multifactorial, and the mechanisms are partially understood (35). Abnormal mineral metabolism, and particularly the accumulation of phosphate,

Address for reprint requests and other correspondence: Y. A. Peña, Unidad de Investigacion, IMIBIC, Hospital Reina Sofía, Avda. Menéndez Pidal s/n, 14004 Córdoba, Spain (e-mail: yolandaalmaden@yahoo.es). plays a central role in the generation of VC $(3,25)$. Chronic inflammation has also been proposed as an important factor in the process of $\mathrm{VC}(34,50)$.

Calcitriol $\left[1,25(\mathrm{OH})_{2} \mathrm{D}_{3}\right]$, the most active metabolite of vitamin $\mathrm{D}$, is a key regulator of mineral metabolism through its direct effect on intestine, kidney, bone, and parathyroid glands. Chronic kidney disease (CKD) patients, often develop secondary hyperparathyroidism $\left(2^{\circ} \mathrm{HPT}\right)$ because of the retention of phosphate and the deficiency of calcitriol synthesis, both due to the reduction of functional renal mass, which eventually lead to hypocalcemia. Thus, in the last decades, therapeutic strategies to control $2^{\circ} \mathrm{HPT}$ incorporated high doses of vitamin D, mainly as calcitriol, that may contribute to the development of VCs (13). The vitamin $\mathrm{D}$ analog 19 -nor- $1,25(\mathrm{OH})_{2} \mathrm{D}_{2}$ (paricalcitol) is now commonly used to treat $2^{\circ} \mathrm{HPT}$ in $\mathrm{CKD}$ patients because it effectively suppress parathyroid hormone but is less calcemic and phosphatemic than calcitriol $(29,53)$.

The administration of calcitriol to CKD patients may cause VC by increasing the serum levels of calcium and phosphate. Other studies (45) have suggested that calcitriol and other vitamin D receptor (VDR) activators such as paricalcitol may have a direct effect on VC that is independent of calcium and phosphorus. Paricalcitol seems to produce less calcification than calcitriol $(4,28,33)$. However, the cellular mechanisms driving the differential effects of calcitriol and paricalcitol on VC have not been elucidated. We hypothesized that factors regulating osteogenic differentiation of vascular smooth muscle cells (VSMCs) may respond differently to calcitriol and paricalcitol.

Bone morphogenetic proteins (BMPs) and proteins of the Wnt family are extremely potent anabolic regulators of bone formation, and both have been implicated in the regulation of VC $(7,17,31,49,51,57)$. BMP2 upregulates transcription factors as the runt-related transcript factor 2 (Runx2/Cbfa1) and the Msh homeobox 2 (Msx2), master regulators of osteogenesis (30). Furthermore, Wnt signaling, which is essential for the commitment of pluripotent mesenchymal cells, has also been shown to be activated during the development of $\mathrm{VC}$ in vivo and in vitro $(5,8,23,31,51)$. Wnt proteins (revised in 26) are a large family of secreted signaling molecules that signal through binding to a coreceptor complex formed by the proteins of the frizzled (Fzd) family and the lipoprotein receptorrelated 5/6 proteins (Lrp5/6). The activation of the canonical 
Wnt pathway results in the inactivation of a destruction complex that phosphorylates $\beta$-catenin and targets it for ubiquitinproteasome-mediated degradation; thus $\beta$-catenin is able to translocate to the nucleus and regulates the expression of target genes.

The aim of the present study was to investigate possible differences between the effect of calcitriol and paricalcitol on osteogenic signals, mainly the $\mathrm{Wnt} / \beta$-catenin signaling, in human aortic smooth muscle cells (HASMCs) in vitro.

\section{MATERIALS AND METHODS}

Cell culture. HASMCs were obtained from Clonetics (Lonza, Walkersville, MD). Cells were cultured in DMEM supplemented with $15 \%$ heat-inactivated FBS (BioWhittaker), Na piruvate $(1 \mathrm{mmol} / \mathrm{l})$, glutamine $(4.5 \mathrm{~g} / \mathrm{l})$, penicillin $(100 \mathrm{U} / \mathrm{ml})$, streptomycin $(100 \mathrm{mg} / \mathrm{ml})$, and HEPES $(20 \mathrm{mmol} / \mathrm{l})$ at $37^{\circ} \mathrm{C}$ in a humidified atmosphere with $5 \%$ $\mathrm{CO}_{2}$. HASMCs of passage 5-8 were used in the experiments. To induce calcification, after reaching $80 \%$ confluence, HASMCs were incubated for 9 days in a high phosphate medium (calcification medium) that contained $\mathrm{Na}_{2} \mathrm{HPO}_{4}^{3-}$ and $\mathrm{NaH}_{2} \mathrm{PO}_{4}^{3-}$ salts in 1:2 proportion (Sigma Aldrich) to obtain a final phosphate concentration of $3.3 \mathrm{mmol} / \mathrm{l}$. The medium was replaced with fresh medium every 2-3 days. Depending on the experiments, calcification medium was supplemented with calcitriol $10^{-8} \mathrm{M}$, paricalcitol $3 \cdot 10^{-8} \mathrm{M}$, or other drugs such as Dickkopf-related protein 1 (DKK-1; ref 5439-DK-010; R\&D Systems; $100 \mathrm{ng} / \mathrm{ml}$; a secreted, endogenous extracellular Wnt/ $\beta$-catenin inhibitory gene product that is commercially available). Cells that were incubated in normal phosphate $(0.9 \mathrm{mmol} / \mathrm{l})$ medium were used as controls.

Assessment of calcium deposition. After 9 days of incubation, calcification was quantified. Cells were decalcified with $\mathrm{HCl}(0.6$ $\mathrm{mol} / \mathrm{l}$ ) for $24 \mathrm{~h}$. The calcium content of the supernatants was determined by spectrophotometer at $612 \mathrm{~nm}$ by a kit containing phenolsulphonephthalein dye (no. DICA008, QuantiChrom calcium assay kit; BioAssay Systems). Then, the cells were washed three times with PBS (Sigma Aldrich) and solubilized in $0.1 \mathrm{~mol} / \mathrm{l} \mathrm{NaOH} / 0.1 \%$ SDS. The protein content was measured using the Bio-Rad protein assay (Bio-Rad Laboratories, Munich, Germany), and the calcium content was normalized for total protein.

Real-time RT-PCR. Total RNA was isolated from each sample of HASMCs using $500 \mu 1$ Trizol (Sigma) by processing according to the manufacturer's recommendation. Real-time RT-PCR was performed in duplicate with QuantiTect SYBR Green one-step RT-PCR Kit (ref. no. 204243; Qiagen) in a final volume of $20 \mathrm{ul}$ from $30 \mathrm{ng}$ of total RNA. All PCR amplifications were carried out using Lightcycler 480 (Roche Molecular Biochemicals, Indianapolis, IN). The expression of target genes was normalized to the expression of GAPDH. The primers for PCR amplification are indicated in Table 1.

Protein extracts and Western blot. Proteins were isolated from HASMCs using lysis buffer containing HEPES (10 mmol/l), $\mathrm{KCl}(10$ $\mathrm{mmol} /)$, EDTA $(0.1 \mathrm{mmol} / \mathrm{l}), \operatorname{EGTA}(0.1 \mathrm{mmol} / \mathrm{l})$, dithiothreitol (1 $\mathrm{mmol} / \mathrm{l})$, PMSF $(0.5 \mathrm{mmol} / \mathrm{l})$, protease inhibitor cocktail $(70 \mathrm{mg} / \mathrm{ml}$; Sigma Aldrich), and Igepal CA-630 (0.6\%) at pH 7.9. The suspension was centrifuged, and the supernatant (cytosolic extract) was stored. Nuclear extracts were obtained by incubating the pellet separated from the cytosolic extract in a lysis buffer containing HEPES (20 $\mathrm{mmol} / \mathrm{l}), \mathrm{NaCl}(0.4 \mathrm{mmol} / \mathrm{l})$, EDTA $(1 \mathrm{mmol} / \mathrm{l})$, EGTA $(1 \mathrm{mmol} / \mathrm{l})$, dithiothreitol $(1 \mathrm{mmol} / \mathrm{l})$, PMSF (1 $\mathrm{mmol} / \mathrm{l})$, and protease inhibitor cocktail $(46 \mathrm{mg} / \mathrm{ml})$ at $\mathrm{pH} 7.9$. Protein concentration was determined with the Bradford method (Bio-Rad Laboratories, Munich, Germany). For Western blot, equal amounts of protein were electrophoresed in $10 \%$ SDS-polyacrylamide gel (Invitrogen, Carlsbad, CA) and subsequently transferred to a nitrocellulose membrane (Invitrogen). The membranes were blocked with $5 \%$ nonfat dried milk for $1 \mathrm{~h}$ at room temperature and then incubated with primary antibody for $2 \mathrm{~h}$ at room temperature. Primary antibodies used included rabbit polyclonal $\beta$-catenin antibody (ref. no. L9562; Cell Signaling) and rabbit polyclonal TFIIB antibody (ref. no. SC-225; Santa Cruz Biotechnology, Santa Cruz, CA). Blots were immunolabeled using a horseradish peroxidase-conjugated secondary antibody and developed on autoradiographic film using the ECL Plus Western blotting detection system (Amersham Biosciences, Little Chalfont, England). Specific bands were quantified by densitometric analyses with Quantity One 4.4.0 software (Bio-Rad Laboratories) and were normalized to TFIIB levels.

Confocal microscopy. Cells were seeded on coverslips, and after reaching $90 \%$ confluence, they received the different treatments for 24 $\mathrm{h}$. Then, they were rinsed in PBS and fixed and permeated in cold 50\% methanol for $2 \mathrm{~min}$, cold $100 \%$ methanol for $20 \mathrm{~min}$, and cold $50 \%$ methanol for $2 \mathrm{~min}$. The specimens were subsequently washed once in PBS $(3 \times 5 \mathrm{~min})$ and incubated for $2 \mathrm{~h}$ with anti- $\beta$-catenin antibody (1:50; BD Pharmigen, Franklin Lakes, NJ) in blocking solution (1\% BSA) at room temperature. After being washed with PBS $(3 \times 5 \mathrm{~min})$, specimens were incubated for $1 \mathrm{~h}$ with Alexa Fluor $488 \mathrm{~F}\left(\mathrm{ab}^{\prime}\right)_{2}$ fragment of rabbit anti-mouse IgG (1:500; ref. no. A-21204; Invitrogen) in PBS containing $1 \%$ BSA. After a final wash with PBS $(3 \times$ $5 \mathrm{~min}$ ), the specimens were counterstained with DAPI for nuclear stain. Cells were mounted on slides to examine fluorescence using a LSM 5 Exciter Carl Zeiss confocal microscope. Pictures were obtained at $\times 40$ in Axio Observer Z1 inverted confocal microscope (LSM5 Exciter Zeiss). ImageJ software (National Institutes of Health) was used to analyze confocal immunofluorescence staining. Mander's coefficient M2 plugin (DAPI vs. green) was used to analyze nuclear translocation of $\beta$-catenin. Mander's coefficient M2 is the percentage of above-background pixels in blue color (DAPI) that overlap abovebackground pixels in green color ( $\beta$-catenin).

Statistical analysis. Results are expressed as means \pm SE. The difference between means for three or more groups was assessed by one-way ANOVA followed by post hoc Duncan analysis. The difference between means for two different groups was determined by $t$-test. A $P$ value $<0.05$ was considered significant. These analyses were performed with the assistance of a computer program (SPSS 15.0, Chicago, IL).

\section{RESULTS}

Effect of calcitriol and paricalcitol on VSMC calcification. Incubation of HASMCs in a high phosphate $(3.3 \mathrm{mmol} / \mathrm{l})$ medium for 9 days (HP) induced calcification compared with

Table 1. Primers used for quantitative real-time RT-PCR

\begin{tabular}{|c|c|c|}
\hline Gene & Sense Primer & Antisense Primer \\
\hline Cyclin D1 & $5^{\prime}$-CCGAGGAGCTGCTGCAAATGGA-3' & 5'-ATGGAGGGCGGATTGGAAATGAAC-3' \\
\hline BMP2 & $5^{\prime}$-AGGAGGCAAAGAAAAGGAACGGAC-3' & $5^{\prime}$-GGAAGCAGCAACGCTAGAAGACAG-3' \\
\hline Runx2 & $5^{\prime}$-CCGGAGTGGACGAGGCAAGAGTT-3' & 5'-AGCTTCTGTCTGTGCCTTCTGGG-3' \\
\hline Osteocalcin & $5^{\prime}$-GCAGAGTCCAGCAAAGGTGCAGCC-3' & $5^{\prime}$-GCCTCCTGAAAGCCGATGTGGTCA-3' \\
\hline
\end{tabular}

BMP2, bone morphogenetic protein 2. 


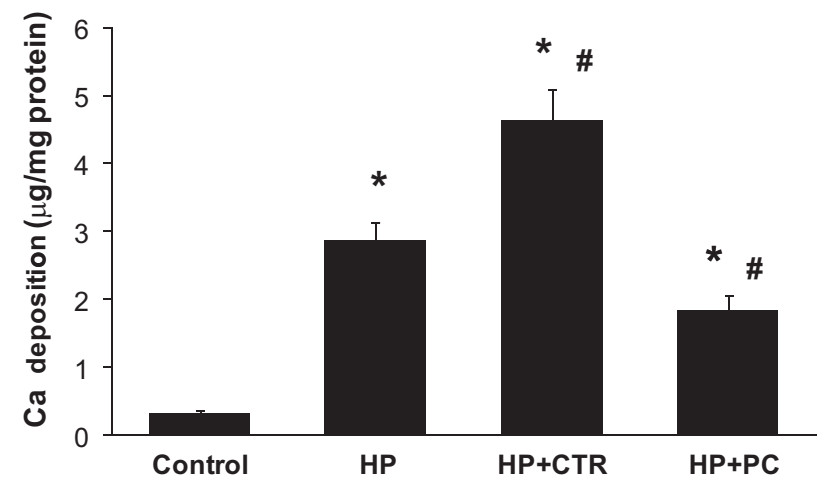

Fig. 1. Effect of calcitriol and paricalcitol on human aortic smooth muscle cell (HASMC) calcification. HASMCs are incubated for 9 days in a high (3.3 $\mathrm{mmol} / \mathrm{l}$ ) phosphate (HP) medium (calcification medium) alone or supplemented with either calcitriol $10^{-8} \mathrm{M}(\mathrm{HP}+\mathrm{CTR})$ or paricalcitol $3 \cdot 10^{-8} \mathrm{M}$ $(\mathrm{HP}+\mathrm{PC})$. Cells incubated in normal phosphate $(0.9 \mathrm{mmol} / \mathrm{l})$ medium are used as controls. Calcium content is determined with the phenolsulphonephthalein dye. Bars are means $\pm \mathrm{SE}$ (5 independent experiments; 6 repetitions in each experiment). ${ }^{*} P<0.05$ vs. control. $\# P<0.05$ vs. HP

cells maintained in a medium with $0.9 \mathrm{mmol} / \mathrm{l}$ phosphate (control; $P<0.05$; Fig. 1$)$. The addition of calcitriol $\left(10^{-8} \mathrm{M}\right)$ to cells in HP medium (HP + CTR) further increased the degree of calcification observed with HP alone $(P<0.05)$. Conversely, the addition of paricalcitol $\left(3 \times 10^{-8} \mathrm{M}\right.$; HP + $\mathrm{PC})$ produced a significant reduction in calcification relative to the observed in cells in HP medium $(P<0.05)$. Nevertheless, in the HP + PC cells the calcium content remained higher than in control cells cultured in $0.9 \mathrm{mmol} / \mathrm{L} \mathrm{P}(P<0.05)$.

Osteoblast phenotype. The levels of BMP2 mRNA were greater in cells incubated in HP medium than in controls $(P<$ 0.05 ; Fig. 2A). The addition of calcitriol further increased the expression of BMP2 mRNA compared with the HP cells $(P<$
0.05). In cells treated with paricalcitol, the levels of BMP2 mRNA were not different from control cells.

The gene expression of the osteoblastic-specific marker Runx2 was significantly increased in cells on HP compared with controls $(P<0.05$; Fig. $2 B)$. Again calcitriol caused additional increase of Runx 2 expression $(P<0.05$ vs. HP cells), whereas paricalcitol failed to increase the expression of Runx2 mRNA beyond the values observed in HP cells.

Similarly to that observed with Runx2, the expression of Msx2 mRNA was increased in HP and further increased by addition of calcitriol (Fig. 2C). The addition of paricalcitol decreased the Msx2 mRNA levels to control values. The expression of Bglap/osteocalcin (OC) was not increased by HP but it increased when calcitriol was added to the HP medium (Fig. 2D). By contrast, paricalcitol did not modify the OC expression.

Role of the canonical Wnt/ $\beta$-catenin signaling pathway. Activation of the $\mathrm{Wnt} / \beta$-catenin signaling pathway results in nuclear translocation of $\beta$-catenin. The presence of $\beta$-catenin in the nucleus was assessed by Western blotting of nuclear extracts. The incubation of cells in HP induced a significant increase of the expression of nuclear $\beta$-catenin compared with controls $(P<0.05)$. The addition of calcitriol to HP medium increased the nuclear content of $\beta$-catenin; however, the addition of paricalcitol caused a reduction in the levels of nuclear $\beta$-catenin to a level similar to that observed in control cells (Fig. 3A). Intracellular localization of $\beta$-catenin was visualized by immunofluorescence using confocal microscopy (Fig. 3B). Control cells showed immunofluorescence staining of $\beta$-catenin only in the cytoplasm, whereas cells cultured in HP showed marked expression of $\beta$-catenin at the nuclear level. HP + CTR cells also exhibited marked staining for nuclear $\beta$-catenin. By contrast, in HP + PC, $\beta$-catenin expression was mainly restricted to the cytoplasm. Quantification by the Mander's

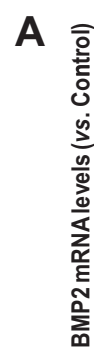

C
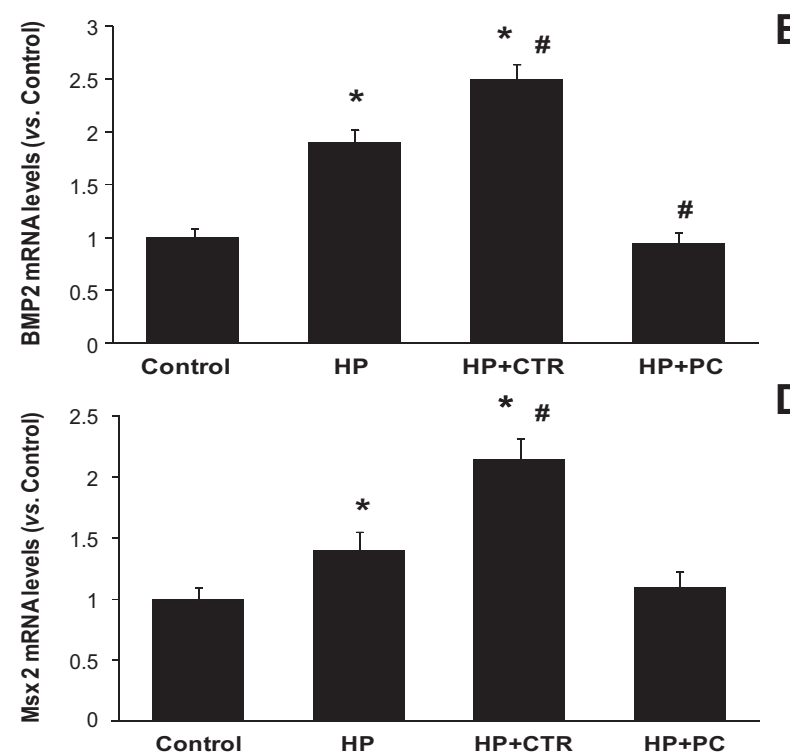
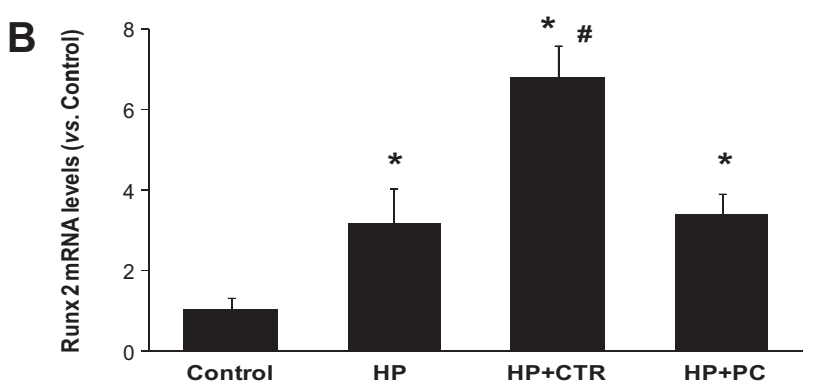

o

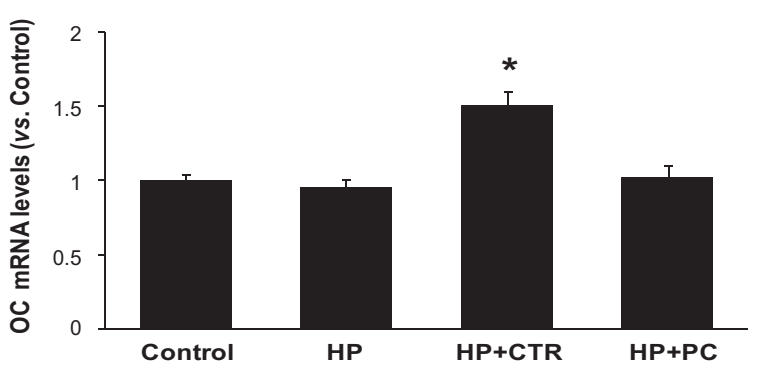

Fig. 2. Effect of calcitriol and paricalcitol on the expression of markers of osteoblastic phenotype during HASMC calcification. HASMCs are incubated for 9 days in a high $(3.3 \mathrm{mmol} / \mathrm{l})$ phosphate (HP) medium (calcification medium) alone or supplemented with either calcitriol $10^{-8} \mathrm{M}$ (HP $\left.+\mathrm{CTR}\right)$ or paricalcitol $3 \cdot 10^{-8} \mathrm{M}(\mathrm{HP}+\mathrm{PC})$. Cells incubated in normal phosphate $(0.9 \mathrm{mmol} / \mathrm{l})$ medium are used as controls. mRNA levels are analyzed by real-time RT-PCR technique. Expression of target genes are normalized to the expression of GAPDH. A: bone morphogenetic protein 2 (BMP2) mRNA expression. B: Runx2/Cbfa1 mRNA expression. $C$ : Msx2 mRNA expression. D: osteocalcin/Bglap mRNA expression. Bars are means \pm SE (3 independent experiments; 6 repetitions in each experiment). OC, osteocalcin. ${ }^{*} P<0.05$ vs. control. $\# P<0.05$ vs. HP. 
A

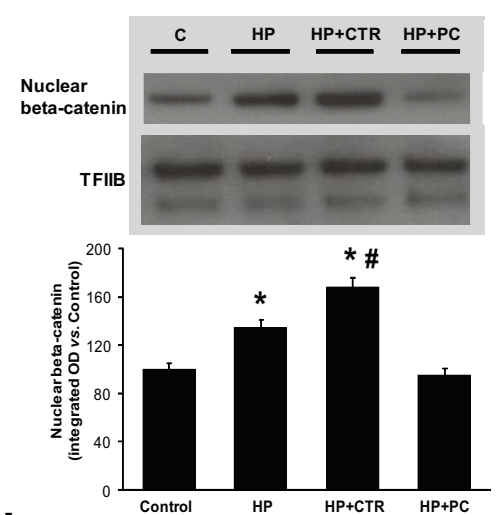

c

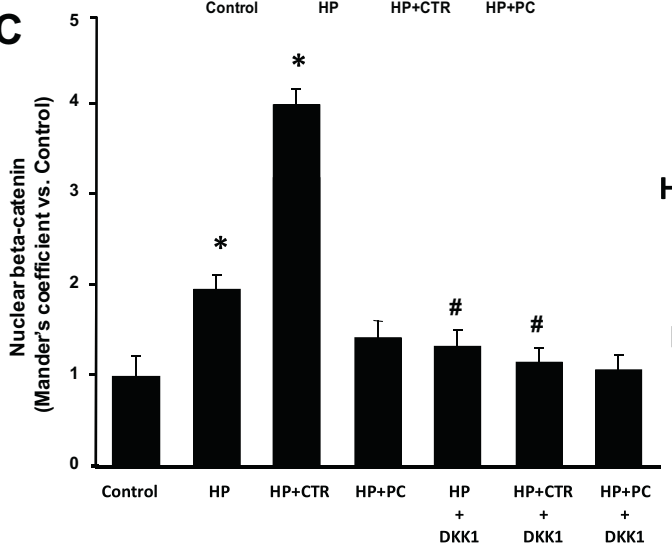

B

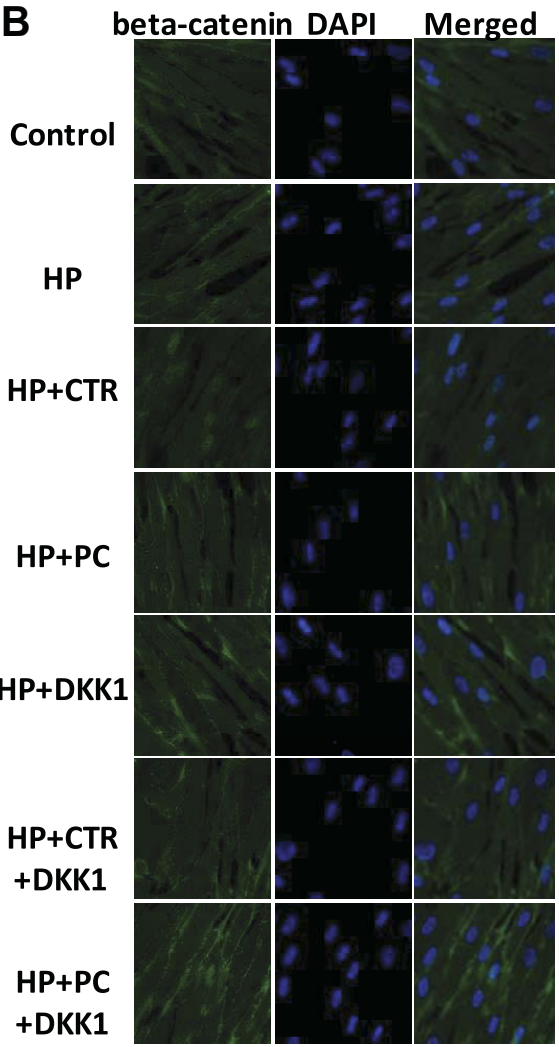

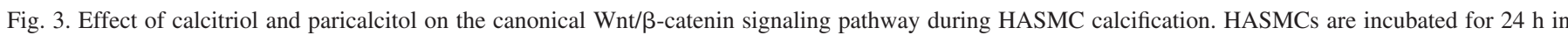

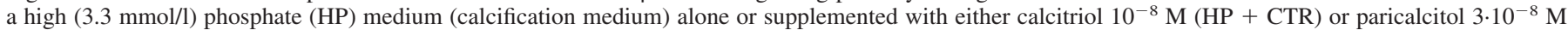

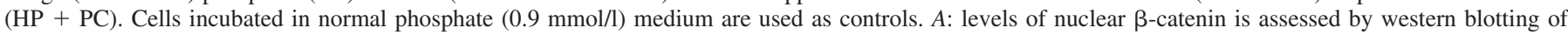

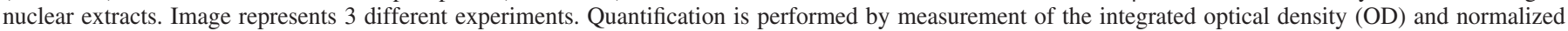

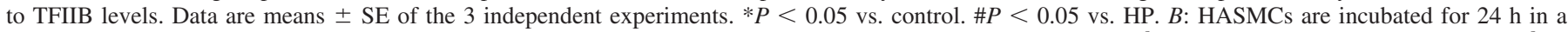

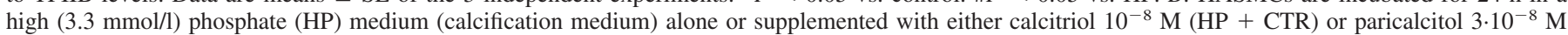

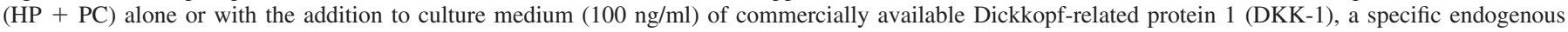

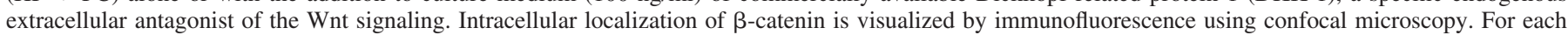

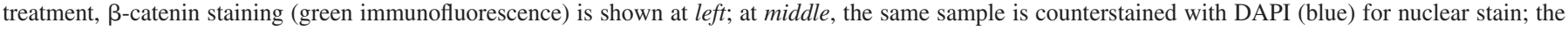

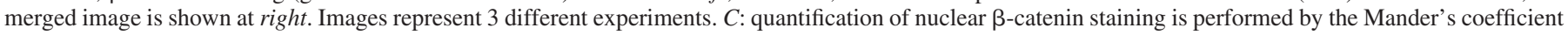
(M2 plugin: DAPI vs. green). ${ }^{*} P<0.05$ vs. control. $\# P<0.05$ vs. the same treatment without DKK-1.

coefficient M2 plugin (DAPI vs. green), confirmed the significance of differences in the levels of $\beta$-catenin fluorescence in HP and HP + CTR compared with control cells $(P<0.05$ and $P<0.05$, respectively; Fig. $3 C$ ).

The relevance of $\mathrm{Wnt} / \beta$-catenin signaling activation in calcification was tested by addition to culture medium $(100 \mathrm{ng} / \mathrm{ml})$ of DKK-1, a commercially available specific endogenous extracellular antagonist of the Wnt signaling $(1,26)$. As shown in Fig. 4, the addition of DKK-1 reduced the level of calcification induced by high phosphate $(P<0.05$ vs. HP cells $)$ and prevented the increase in calcification induced by calcitriol $(P<0.05$ vs. HP + CTR cells $)$; a trend toward a decreased calcification, although not significant, was also observed after addition of DKK-1 to HP + PC cells. The effect of DKK-1 on $\beta$-catenin translocation was also evaluated by confocal immunofluorescence (Fig. 3, $B$ and $C$ ). The increase of nuclear $\beta$-catenin expression in HP and HP + CTR cells was abolished by coincubation with DKK-1 ( $P<0.05$ vs. controls).

Additional direct $\mathrm{Wnt} / \beta$-catenin transcriptional targets were examined, including cyclin D1 (an early marker of cells entering the cell cycle), VCAN/versican (a large chondroitin sulfate proteoglycan; a member of the aggrecan/versican proteoglycan family), and axin 2 (axis inhibition protein 2 or conductin; a member of the $\mathrm{Wnt} / \beta$-catenin signaling pathway that regulates the stability of $\beta$-catenin). Effects of cotreatment with the inhibitor DKK-1 on the expression of genes were also tested (Fig. 5). The mRNA expression of cyclin D1 was similarly elevated in cells in HP and HP + CTR compared with control cells $(P<0.05)$. In cells treated with $\mathrm{HP}+\mathrm{PC}$, the cyclin D1 mRNA level was greater than in control $(P<0.05)$ but lower than in HP and HP + CTR cells $(P<0.05)$. Addition of DKK-1 dramatically reduced cyclin D1 mRNA to a level not different from that of control. VCAN expression was also increased in HP, HP + CTR, and HP + PC cells over control $(P<0.05)$. Cotreatment with DKK-1 significantly reduced VCAN mRNA levels to control values in all the groups. Finally, compared with control, axin 2 mRNA expression was elevated in HP and HP + CTR $(P<0.05)$ but not in HP + PC group; this increase was abolished by DKK-1 $(P<0.05)$.

\section{DISCUSSION}

In the present study, we have explored the differential effect of two VDR agonists, calcitriol and paricalcitol, on VSMC 


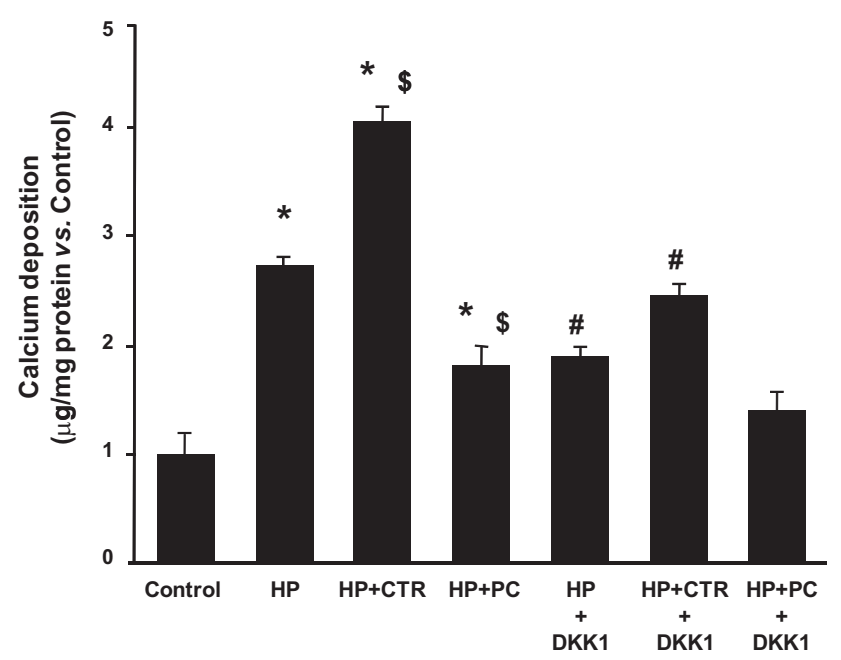

Fig. 4. Effect of the inhibition of the canonical Wnt/ $\beta$-catenin signaling pathway by DKK-1 on HASMC. HASMCs are incubated for $24 \mathrm{~h}$ in a high $(3.3 \mathrm{mmol} / \mathrm{l})$ phosphate (HP) medium (calcification medium) alone or supplemented with either calcitriol $10^{-8} \mathrm{M}\left(\mathrm{HP}+\mathrm{CTR}\right.$ ) or paricalcitol $3 \cdot 10^{-8} \mathrm{M}$ $(\mathrm{HP}+\mathrm{PC})$ alone or with the addition to culture medium $(100 \mathrm{ng} / \mathrm{ml})$ of commercially available DKK-1, a specific endogenous extracellular antagonist of the Wnt signaling. Cells incubated in normal phosphate $(0.9 \mathrm{mmol} / \mathrm{l})$ medium are used as controls. Calcium content is determined with the phenolsulphonephthalein dye. Bars are means \pm SE (3 independent experiments; 6 repetitions in each experiment). ${ }^{*} P<0.05$ vs. control. $\$ P<0.05$ vs. HP. $\# P<0.05$ vs. the same treatment without DKK-1.

calcification in vitro. We found that calcitriol increased calcification, which appeared to be associated with the activation of the Wnt/ $\beta$-catenin and BMP2 signaling pathways. By contrast, paricalcitol decreased calcification, which was accompanied by an inhibition of the Wnt/ $\beta$-catenin pathway and downregulation of osteoblastic gene expression.

As previously demonstrated by us and other researchers $(6$, 36, 40, 44, 47, 49, 58), VSMCs cultured in high phosphate undergo osteogenic transformation and calcification. BMPs and Wnt ligands have been implicated in the regulation of both osteoblastic transdifferentiation of aortic VSMCs in vitro and $\operatorname{VC}(7,17,31,49,51,57)$. In our study, we found that the calcification process was associated with the upregulation of osteogenic factors such as BMP2, the transcription factors Runx2/Cbfa1 and Msx2, and the procalcificant protein OC. This is in agreement with previous results (56) showing that the expression of all these markers was significantly induced in calcified vessels. BMP2 is a key factor for osteogenic differentiation of mesenchymal cells that upregulates Runx2 and Msx2 (30). OC is a downstream target gene of Runx2 and Msx2 (16).

In the present study, we also show that calcification of the HASMCs is also associated with a concomitant activation of the canonical $W n t / \beta$-catenin signaling pathway. This was quantitatively demonstrated both immunocytochemically by the translocation of $\beta$-catenin into the nucleus and by the significant increase of the expression of nuclear $\beta$-catenin by Western blotting. Furthermore, the addition of DKK-1, a secreted, endogenous extracellular Wnt/ $\beta$-catenin inhibitory gene product $(1,26)$ that is commercially available, inhibited the calcification and the concomitant cellular changes induced by high phosphate.
The activation of $\beta$-catenin signaling modulates osteoblast proliferation and differentiation $(32,41)$. Other authors (22) observed VSMC proliferation in vessels developing calcification. Notably, we demonstrated that the calcification observed in the high phosphate-treated cells was accompanied by a
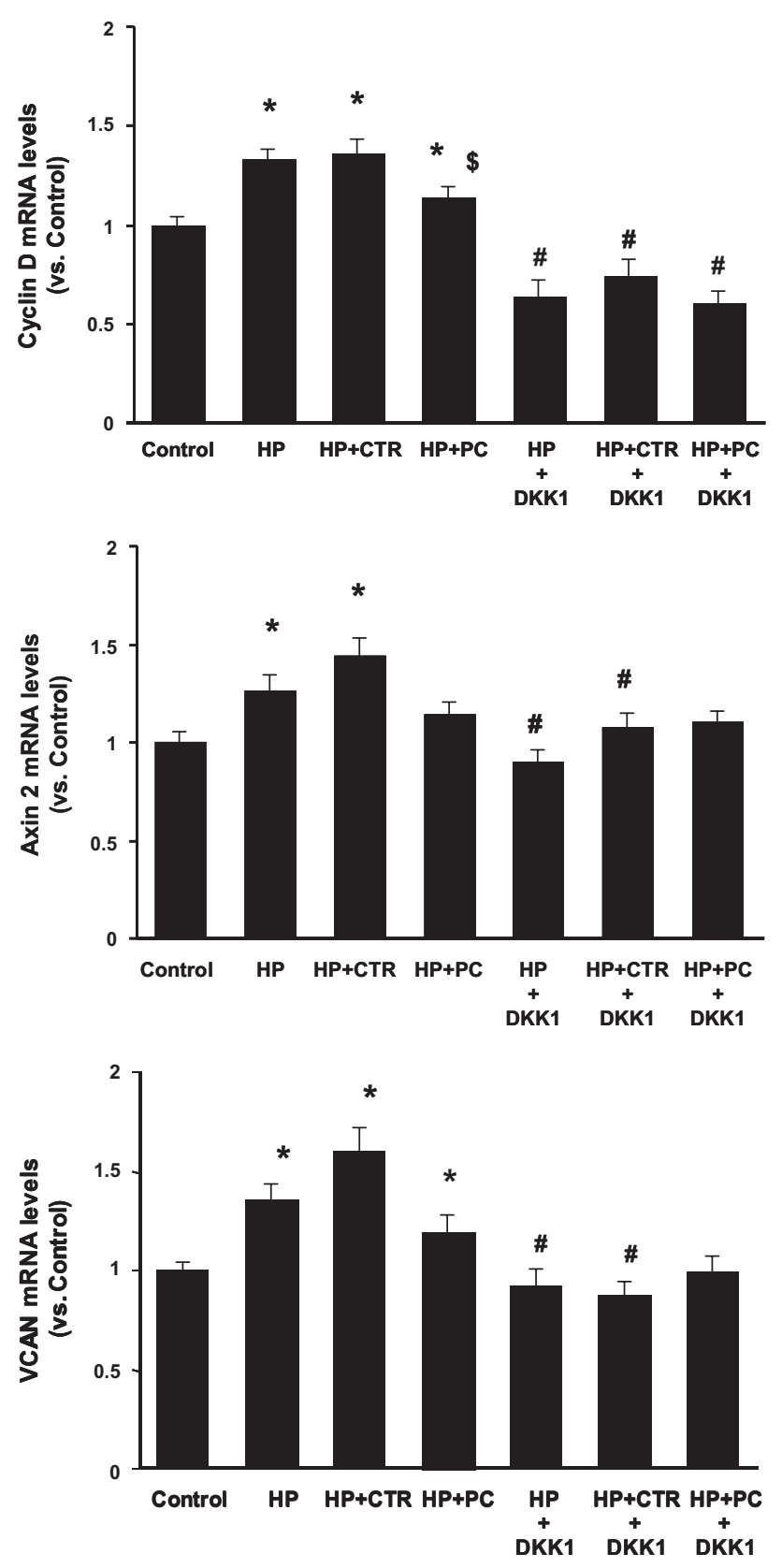

Fig. 5. Effect of calcitriol and paricalcitol on the expression of $\beta$-catenin direct transcriptional target genes, cyclin D1, axin 2, and VCAN/versican, during HASMC. HASMCs are incubated for $24 \mathrm{~h}$ in a high $(3.3 \mathrm{mmol} / \mathrm{l})$ phosphate (HP) medium (calcification medium) alone or supplemented with either calcitriol $10^{-8} \mathrm{M}(\mathrm{HP}+\mathrm{CTR})$ or paricalcitol $3 \cdot 10^{-8} \mathrm{M}(\mathrm{HP}+\mathrm{PC})$ alone or with the addition to culture medium $(100 \mathrm{ng} / \mathrm{ml})$ of commercially available DKK-1, a specific endogenous extracellular antagonist of the Wnt signaling. Cells incubated in normal phosphate $(0.9 \mathrm{mmol} / \mathrm{l})$ medium are used as controls. mRNA levels are analyzed by real-time RT-PCR technique. Expression of target gene mRNA is normalized to the expression of GAPDH. Bars are means $\pm \mathrm{SE}$ ( 3 independent experiments; 6 repetitions in each experiment). $* P<0.05$ vs. control. $\$ P<0.05$ vs. HP. \#P<0.05 vs. the same treatment without DKK-1. 
significant increase in the expression of cylin D1, an early marker of cell proliferation. Cyclin D1 has been shown to be a direct target gene of the activation of the canonical Wnt/ $\beta$ catenin (52), and it is required for propagation of specific types of osteoprogenitors at various developmental stages (32). Importantly, it has also been shown to be upregulated in VSMCs in response to Wnt signaling (59). Thus the increase of the cyclin D1 mRNA levels that we have observed is in accordance with previous data $(5,41)$ reporting that in the vasculature nuclear $\beta$-catenin signals may drive VSMC proliferation. The upregulation of this and other direct transcriptional target genes as axin 2 (62) and VCAN (42), as well as the abrogation of this effect by DKK-1 that we have observed in this study, is consistent with the activating effect of the $\mathrm{Wnt} / \beta$-catenin signaling on $\mathrm{VC}$ of HASMCs.

The role of BMP and Wnt signaling on $\mathrm{VC}$ remains to be elucidated (31). Both contribute to the regulation of bone mass by promoting osteogenesis through the direct stimulation of Runx2 gene expression (12). However, the molecular interactions between these pathways in osteoblast differentiation and bone formation are not totally defined (20). Most studies have suggested that BMP acts upstream of Wnt signaling (20). The study by Rawadi et al. (43) showed that the capacity of BMP2 and Shh (Sonic hedgehog homolog gene) to induce alkaline phosphatase relies on Wnt expression and the effects of BMP2 on extracellular matrix mineralization by osteoblasts are mediated by the induction of a canonical Wnt/ $\beta$ catenin autocrine loop. In a recent study, Rodriguez-Carballo et al. (46) investigated the cooperative effects of BMP and the Wnt canonical pathway on the expression of the early osteogenic master genes Dlx5, Msx2, and Runx2 in osteoblast differentiation. They found that induction of these genes is mediated by the formation of both protein-protein interactions between them and cooperative transcriptional complexes of BMP-dependent-activated Smads and TCF4/ $\beta$-catenin that bind to DNA-binding sites. BMPs and Wnt ligands have also been implicated in the regulation of osteoblastic transdifferentiation of VSMCs (31). The studies of Towler and colleagues $(5,34,51)$ with different in vivo and in vitro models described the involvement of a BMP-Wnt/ $\beta$-catenin axis in the osteogenic regulation of $\mathrm{VC}$. Nonetheless, canonical Wnt/ $\beta$-catenin signaling acting upstream of BMP signaling has been also reported. This is the case for the regulation of dorsoventral polarity in the limb (54) or the inhibition of oligodendrocyte maturation (9) during development. We are aware of one single study (55) on this Wnt-BMP hierarchy in osteoblast differentiation, which shows that osthole, a coumarin-like derivative extracted from Chinese herbs, stimulated osteoblast differentiation through a Wnt/ $\beta$ catenin dependent induction of BMP2 expression.

On the other hand, the relative contribution of canonical and noncanonical Wnts in the regulation of $\mathrm{VC}$ has to be explored further (51). Indeed, the role of Wnt signaling in osteogenic differentiation during bone development is still controversial. Canonical Wnt signaling may suppress osteogenic differentiation or activate osteogenesis under certain cellular conditions. Lack of uniformity in the literature may have resulted from differences in baseline cellular conditions, species employed, or even in the experimental conditions and stimuli applied (26). The effect of noncanonical Wnt activation through Wnt5a in osteogenesis has been demonstrated in adult stem cells (48) and MC3T3E1 (preosteoblasts) cells (11). The specific Wnt milieu regulating $\mathrm{VC}$ is unknown; 19 murine Wnt genes exist and both canonical agonists (Wnt3a, Wnt7) and noncanonical ligands (Wnt5) that inhibit canonical Wnt actions were upregulated in an Msx2-dependent cardiovascular calcification model in vivo (51). Whether phosphate could be a new stimulator of noncanonical Wnt pathways is presently unknown.

Many in vivo studies $(2,4,14,15,27,33)$ have reported that the treatment of uremic animals with vitamin D produces an increase in VC. Koleganova et al. (22) showed that a moderate dose of calcitriol produced $\mathrm{VC}$ in both sham and uremic rats. This effect was observed despite no changes in serum levels of calcium and phosphate, suggesting that calcitriol may directly affect VC. Interestingly, in a model of uremic rats, the induction of aortic calcifications by calcitriol was partially reversible after discontinuation of calcitriol administration (2). In vitro studies were performed to evaluate a direct effect of calcitriol on VSMCs calcification. Jono et al. (19) showed that in VSMCs cultured with high phosphate, the addition of an increasing concentration of calcitriol produced a dose-dependent increase in calcification. Recently, Zebger and Gong (63) observed that a high-dose calcitriol treatment induced transformation of VSMCs into osteoblastic phenotype both in uremic rats and in vitro; this was associated with upregulation of proteins regulating mineralization and the osteogenic transcription factor Osterix.

In the present study, we assessed the effect of calcitriol and paricalcitol at concentrations usually tested in in vitro studies with VSMCs $(4,18,49)$, which are in accordance with their therapeutic dosages in vivo. The results show that cells exposed to calcitriol exhibited a significant increase in calcification; by contrast, the addition of paricalcitol to the medium resulted in a significant decrease of calcification. Previous experimental studies $(4,28,33)$ have shown that paricalcitol produced less calcification than calcitriol. Thus here we confirm that paricalcitol also exerts beneficial effects on the development of VCs. Importantly, paricalcitol tended to suppress the calcification induced by phosphate; this is in marked contrast with calcitriol that worsens the calcification induced by phosphate.

To better understand the molecular mechanisms supporting the opposed effects of calcitriol and paricalcitol on calcification, we examined the expression of the BMP2 signaling genes that appeared to be upregulated in the VSMCs exposed to high phosphate. Whereas calcitriol increased BMP2 mRNA level, paricalcitol decreased it. Consistent with this was the upregulation of Runx2 and Msx2 in cells treated with calcitriol and the downregulation of Runx2 and Msx2 in cells exposed to paricalcitol. The expression of OC was also increased by calcitriol, but no change was observed in cells exposed to paricalcitol. In addition, calcitriol did not change the upregulation of cyclin D1 induced by the high phosphate medium whereas paricalcitol tended to reduce it. Collectively, these results indicate that calcitriol and paricalcitol induced a different phenotype profile driving human aortic VSMCs toward the stimulation and the inhibition of the calcification process respectively. This is in line with previous results showing an increased expression of Runx 2 in the aorta of calcitriol-treated animals (22), while both Runx 2 expression and OC expression were upregulated in the aorta by calcitriol and doxercalciferol but not by paricalcitol (33). 
Following ligand activation, the VDR binds directly to specific sequences located near promoters and recruits a variety of coregulatory complexes that perform the additional functions required to modify transcriptional output (39). Thus different cell events after activation of the same VDR may explain why some vitamin D analogs may not promote VC. It has been demonstrated that the activation of the VDR by paricalcitol or 22-oxacalcitriol recruits coactivators that are different from those recruited by calcitriol (18). Additionally, the differential effect on the calcification process that we have observed could be explained by a differential modulation of intracellular signaling pathways. As indicated above, we have demonstrated in human aortic VSMCs the involvement of Wnt/ $\beta$-catenin activation in the calcification induced by high phosphate. Thus we then explored the effect of calcitriol and paricalcitol on the Wnt/ $\beta$-catenin pathway. The increase in calcification induced by calcitriol was accompanied with a concomitant activation of the $\mathrm{Wnt} / \beta$-catenin with the nuclear translocation of $\beta$-catenin. This is in agreement with previous data showing that Wnt signaling proteins are implicated in bovine artery smooth muscle cell calcification in the presence of phosphate and vitamin D sterols (49). In addition, we further verified the implication of $\mathrm{Wnt} / \beta$-catenin activation on calcitriol-induced calcification by demonstrating a reduction on calcification after inhibition of Wnt/ $\beta$-catenin by coincubation with the specific Wnt antagonist DKK-1. The effect of paricalcitol on the Wnt/ $\beta$-catenin pathway was the opposed from that seen with calcitriol. The inhibition of calcification by paricalcitol was accompanied by a reduction in nuclear $\beta$-catenin expression to levels even lower than those observed with high phosphate in the medium. Thus our data clearly demonstrate a differential effect of calcitriol and paricalcitol on the Wnt/ß-catenin signaling pathway.

Of note, it has been reported that the VDR can interact with $\beta$-catenin via a noncanonical signaling to control different cell responses $(38,24)$. Of interest, Pálmer et al. (37) showed that a number of genes induced by $\beta$-catenin are regulated through VDR elements. Thus combined activation of VDR and Wnt signaling promoted formation of TCF/Lef- $\beta$-catenin and VDR/ $\beta$-catenin complexes that together induced genes involved in hair follicle differentiation in adult epidermis; furthermore, the vitamin D analog EB1089 synergized with $\beta$-catenin to stimulate hair differentiation. A functional interaction between the Wnt and $1,25(\mathrm{OH})_{2} \mathrm{D}_{3}$ pathways has also been proposed in osteoblasts. Interestingly, VDR activation by $1,25-(\mathrm{OH})_{2} \mathrm{D}_{3}$ caused upregulation of low-density lipoprotein receptor-related protein 5, a Wnt coreceptor that plays an important role in bone formation $(10,21)$, through its binding to a VDR element (10). It is tentative to hypothesize that $\mathrm{VDR} / \beta$-catenin interactions have a role in the development of $\mathrm{VC}$ and therefore it may be affected by calcitriol or paricalcitol. The regulatory role of Wnt signaling in VCs emerges the possibility of their therapeutic intervention by targeting this pathway. Indeed, Wnt inhibitors have shown early promise; however, given the central role of the Wnt pathway in regulating growth and development in many tissues, considerable work will be needed to ensure the safety of these new therapies (60).

In summary, our results suggest differential effects of calcitriol and paricalcitol on VC that appears to be mediated by a distinct regulation of the BMP and $\mathrm{Wnt} / \beta$-catenin signaling pathways. Calcitriol increased the calcification, which ap- peared to be associated with the upregulation of the expression of osteoblastic gene markers as BMP2, Runx2, Msx2, and OC and the activation of the $\mathrm{Wnt} / \beta$-catenin signaling pathway. By contrast, paricalcitol decreased calcification, which was accompanied by a downregulation of the expression of these osteoblastic gene markers and the $\mathrm{Wnt} / \beta$-catenin signaling.

\section{ACKNOWLEDGMENTS}

The technical assistance in confocal microscopy of M. Esther Peralbo (Instituto Maimónides de Investigación Biomédica de Córdoba) is gratefully acknowledged.

\section{GRANTS}

This study was supported by Instituto de Salud Carlos III (FIS 10/1311, FIS 11/02055), Consejeria de Salud (JA 0127/2008), a UE Grant from Framework Programme 7 Syskid (FP7-241544) and Consejeria de Innovacion, Ciencia y Empresa (CTS-5205) of Junta de Andalucia. Y. Almadén is a senior researcher supported by the Fundacion Progreso y Salud, Consejeria de Salud (Junta de Andalucia).

\section{DISCLOSURES}

M. Rodriguez has received research grants from Amgen and Fresenius and lecture fees from the following companies: Amgen, Abbott, Shire, and Fresenius.

\section{AUTHOR CONTRIBUTIONS}

Author contributions: J.M.M.-M., A.C., M.R., and Y.A. conception and design of research; J.M.M.-M., J.R.M.-C., C.H., A.M.d.O., J.-C.E., R.C., M.E.R.-O., P.P.-M., A.C., and Y.A. performed experiments; J.M.M.-M., J.R.M.-C., P.P.-M., A.C., M.R., and Y.A. analyzed data; J.M.M.-M., J.R.M.C., E.A.-T., A.C., M.R., and Y.A. interpreted results of experiments; J.M.M.M., A.C., and Y.A. prepared figures; J.M.M.-M., A.C., M.R., and Y.A. drafted manuscript; J.M.M.-M., J.R.M.-C., J.-C.E., E.A.-T., A.C., M.R., and Y.A. edited and revised manuscript; J.M.M.-M., J.R.M.-C., C.H., A.M.d.O., J.-C.E., R.C., M.E.R.-O., P.P.-M., E.A.-T., A.C., M.R., and Y.A. approved final version of manuscript.

\section{REFERENCES}

1. Bafico A, Liu G, Yaniv A, Gazit A, Aaronson SA. Novel mechanism of Wnt signaling inhibition mediated by Dickkopf-1 interaction with LRP6/ Arrow. Nat Cell Biol 3: 683-686, 2001.

2. Bas A, Lopez I, Perez J, Rodriguez M, Aguilera-Tejero E. Reversibility of calcitriol-induced medial artery calcification in rats with intact renal function. J Bone Miner Res 21: 484-490, 2006.

3. Block GA, Hulbert-Shearon TE, Levin NW, Port FK. Association of serum phosphorus and calcium phosphate product with mortality risk in chronic hemodialysis patients: a national study. Am J Kidney Dis 31: 607-617, 1998.

4. Cardús A, Panizo S, Parisi E, Fernandez E, Valdivielso JM. Differential effects of vitamin D analogs on vascular calcification. J Bone Miner Res 22: 860-866, 2007.

5. Cheng SL, Shao JS, Halstead LR, Distelhorst K, Sierra O, Towler DA. Activation of vascular smooth muscle parathyroid hormone receptor inhibits Wnt/ $\beta$-catenin signaling and aortic fibrosis in diabetic arteriosclerosis. Circ Res 107: 271-282, 2010.

6. Ciceri P, Volpi E, Brenna I, Arnaboldi L, Neri L, Brancaccio D, Cozzolino M. Combined effects of ascorbic acid and phosphate on rat VSMC osteoblastic differentiation. Nephrol Dial Transplant 27: 122-127, 2012.

7. Demer LL, Tintut Y. Vascular calcification: pathobiology of multifaceted disease. Circulation 117: 2938-2948, 2008.

8. Faverman L, Mikhaylova L, Malmquist J, Nurminskaya M. Extracellular transglutaminase 2 activates $\beta$-catenin signaling in calcifying vascular smooth muscle cells. FEBS Lett 582: 1552-1557, 2008.

9. Feigenson K, Reid M, See J, Crenshaw EB III, Grinspan JB. Canonical Wnt signalling requires the BMP pathway to inhibit oligodendrocyte maturation. ASN Neuro 3: e00061, 2011.

10. Fretz JA, Zella LA, Kim S, Shevde NK, Pike JW. 1,25-Dihydroxyvitamin D3 regulates the expression of low density lipoprotein receptorrelated protein 5 via deoxyribonucleic acid sequence elements located 
downstream of the start site of transcription. Mol Endocrinol 20: 22152230, 2006.

11. Friedman MS, Oyserman SM, Hankenson KD. Wnt11 promotes osteoblast maturation and mineralization through R-spondin 2. J Biol Chem 284: 14117-14125, 2009.

12. Gaur T, Lengner CJ, Hovhannisyan H, Bha RA, Bodine PV, Komm BS, Javed A, van Wijnen AJ, Stein JL, Stein GS, Lian JB. Canonical WNT signaling promotes osteogenesis by directly stimulating Runx 2 gene expression. J Biol Chem 280: 33132-33140, 2005.

13. Goodman WG. The consequences of uncontrolled secondary hyperparathyroidism and its treatment in chronic kidney disease. Semin Dial 17: 209-216, 2004.

14. Henley C, Colloton M, Cattley RC, Shatzen E, Towler DA, Lacey D, Martin D. 1,25-Dihydroxyvitamin D3 but not cinacalcet $\mathrm{HCl}$ (Sensipar/ Mimpara) treatment mediates aortic calcification in a rat model of secondary hyperparathyroidism. Nephrol Dial Transplant 20: 1370-1377, 2005

15. Hirata M, Katsumata K, Endo K, Fukushima N, Ohkawa H, Fukagawa M. In subtotally nephrectomized rats 22-oxacalcitriol suppresses parathyroid hormone with less risk of cardiovascular calcification or deterioration of residual renal function than $1,25(\mathrm{OH}) 2$ vitamin D3. Nephrol Dial Transplant 18: 1770-1776, 2003.

16. Hopyan S, Gokgoz N, Bell RS, Andrulis IL, Alman BA, Wunder JS. Expression of osteocalcin and its transcriptional regulators core-binding factor alpha 1 and MSX2 in osteoid-forming tumours. J Orthop Res 17: 633-638, 1999.

17. Hruska KA, Mathew S, Saab G. Bone morphogenetic proteins in vascular calcification. Circulation 97: 105-114, 2005.

18. Issa LL, Leong GM, Sutherland RL, Eisman JA. Vitamin D analoguespecific recruitment of vitamin D receptor coactivators. J Bone Miner Res 17: 879-890, 2002.

19. Jono S, Nishizawa Y, Shioi A, Morii H. 1,25-Dihydroxyvitamin D3 increases in vitro vascular calcification by modulating secretion of endogenous parathyroid hormone-related peptide. Circulation 98: 1302-1306, 1998.

20. Kamiya N, Kobayashi T, Mochida Y, Yu PB, Yamauchi M, Kronenberg HM, Mishina Y. Wnt inhibitors Dkk1 and Sost are downstream targets of BMP signaling through the type IA receptor (BMPRIA) in osteoblasts. J Bone Miner Res 25: 200-210, 2010.

21. Kato M, Patel MS, Levasseur R, Lobov I, Chang BH, Glass DA, 2nd Hartmann C, Li L, Hwang TH, Brayton CF, Lang RA, Karsenty G, Chan L. Cbfa1-independent decrease in osteoblast proliferation, osteopenia, and persistent embryonic eye vascularization in mice deficient in Lrp5, a Wnt coreceptor. J Cell Biol 157: 303-314, 2002.

22. Koleganova N, Piecha G, Ritz E, Schmitt CP, Gross ML. A calcimimetic (R-568), but not calcitriol, prevents vascular remodeling in uremia. Kidney Int 75: 60-71, 2009.

23. Komori T. Signaling networks in RUNX2-dependent bone development. J Cell Biochem 112: 750-755, 2011.

24. Larriba MJ, Ordóñez-Morán P, Chicote I, Martín-Fernández G, Puig I, Muñoz A, Pálmer HG. Vitamin D receptor deficiency enhances Wnt/ $\beta$-catenin signaling and tumor burden in colon cancer. PLos One 6(8): e23524, 2011.

25. Lau WL, Festing MH, Giachelli CM. Phosphate and vascular calcification: emerging role of the sodium-dependent phosphate cotransporter PiT-1. Thromb Haemost 104: 464-470, 2010.

26. Ling L, Nurcombe V, Cool SM. Wnt signaling controls the fate of mesenchymal stem cells. Gene 433: 1-7, 2009.

27. Lopez I, Aguilera-Tejero E, Mendoza FJ, Almaden Y, Perez J, Martin D, Rodriguez M. Calcimimetic R-568 decreases extraosseous calcifications in uremic rats treated with calcitriol. J Am Soc Nephrol 17: 795-804, 2006

28. Lopez I, Mendoza FJ, Aguilera-Tejero E, Perez J, Guerrero F, Martin D, Rodriguez M. The effect of calcitriol, paricalcitol, and a calcimimetic on extraosseous calcifications in uremic rats. Kidney Int 73: 300-307, 2008.

29. Martin KJ, González EA, Gellens M, Hamm LL, Abboud H, Lindberg J. 19-nor-1,25-dihydroxyvitamin D2 safely and effectively reduces the levels of intact parathyroid hormone in patients on hemodialysis. J Am Soc Nephrol 9: 1427-1432, 1998.

30. Matsubara T, Kida K, Yamaguchi A, Hata K, Ichida F, Meguro H, Aburatani H, Nishimura R, Yoneda TB. BMP2 regulates Osterix through Msx2 and Runx2 during osteoblast differentiation. J Biol Chem 83: $29119-29125,2008$
31. Mikhaylova L, Malmquist J, Nurminskaya M. Regulation of in vitro vascular calcification by BMP4, VEGF and Wnt3a. Calcif Tissue Int 81: 372-381, 2007

32. Mirando AJ, Maruyama T, Fu J, Yu HM, Hsu W. $\beta$-catenin/cyclin D1 mediated development of suture mesenchyme in calvarial morphogenesis. BMC Dev Biol 10: 116, 2010.

33. Mizobuchi M, Finch JL, Martin DR, Slatopolsky E. Differential effects of vitamin D receptor activators on vascular calcification in uremic rats. Kidney Int 72: 709-715, 2007.

34. Mizobuchi M, Towler D, Slatopolsky E. Vascular calcification: the killer of patients with chronic kidney disease. J Am Soc Nephrol 20: 1453-1464, 2009.

35. Moe SM, Chen NX. Mechanisms of vascular calcification in chronic kidney disease. J Am Soc Nephrol 19: 213-216, 2008.

36. Montes de Oca A, Madueño JA, Martinez-Moreno JM, Guerrero F, Muñoz-Castañeda J, Rodriguez-Ortiz ME, Mendoza FJ, Almaden Y, Lopez I, Rodriguez M, Aguilera-Tejero E. High-phosphate-induced calcification is related to SM $22 \alpha$ promoter methylation in vascular smooth muscle cells. J Bone Miner Res 25: 1996-2005, 2010.

37. Pálmer HG, Anjos-Afonso F, Carmeliet G, Takeda H, Watt FM. The vitamin $\mathrm{D}$ receptor is a Wnt effector that controls hair follicle differentiation and specifies tumor type in adult epidermis. PLos One 23: e1483, 2008.

38. Pendás-Franco N, Aguilera O, Pereira F, González-Sancho JM, Munoz A. Vitamin D and Wnt/ $\beta$-catenin pathway in colon cancer: role and regulation of DICKKOPF genes. Anticancer Res 28: 2613-2623, 2008.

39. Pike JW, Meyer MB. The vitamin D receptor: new paradigms for the regulation of gene expression by 1,25-dihydroxyvitamin D3. Rheum Dis Clin North Am 38: 13-27, 2012.

40. Prosdocimo DA, Wyler SC, Romani AM, O'Neill WC, Dubyak GR. Regulation of vascular smooth muscle cell calcification by extracellular pyrophosphate homeostasis: synergistic modulation by cyclic AMP and hyperphosphatemia. Am J Physiol Cell Physiol 298: C702-C713, 2010.

41. Quasnichka H, Slater SC, Beeching CA, Boehm M, Sala-Newby GB, George SJ. Regulation of smooth muscle cell proliferation by $\beta$-catenin/ T-cell factor signaling involves modulation of cyclin D1 and p21 expression. Circ Res 99: 1329-1337, 2006.

42. Rahmani M, Read JT, Carthy JM, McDonald PC, Wong BW, Esfandiarei M, Si X, Luo Z, Luo H, Rennie PS, McManus BM. Regulation of the versican promoter by the $\beta$-catenin-T-cell factor complex in vascular smooth muscle cells. J Biol Chem 280: 13019-13028, 2005.

43. Rawadi G, Vayssière B, Dunn F, Baron R, Roman-Roman S. BMP-2 controls alkaline phosphatase expression and osteoblast mineralization by a Wnt autocrine loop. J Bone Miner Res 18: 1842-1853, 2003.

44. Reynolds JL, Joannides AJ, Skepper JN, Mc-Nair R, Schurgers LJ, Proudfoot D, Jahnen-Dechent W, Weissberg PL, Shanahan CM. Human vascular smooth muscle cells undergo vesicle-mediated calcification in response to changes in extracellular calcium and phosphate concentrations: a potential mechanism for accelerated vascular calcification in ESRD. J Am Soc Nephrol 15: 2857-2867, 2004.

45. Rodriguez M, Martinez-Moreno JM, Rodríguez-Ortiz ME, MuñozCastañeda JR, Almaden Y. Vitamin D and vascular calcification in chronic kidney disease. Kidney Blood Press Res 34: 261-268, 2011.

46. Rodríguez-Carballo E, Ulsamer A, Susperregui AR, ManzanaresCéspedes C, Sánchez-García E, Bartrons R, Rosa JL, Ventura F. Conserved regulatory motifs in osteogenic gene promoters integrate cooperative effects of canonical Wnt and BMP pathways. $J$ Bone Miner Res 26: 718-729, 2011.

47. Sage AP, Lu J, Tintut Y, Demer LL. Hyperphosphatemia-induced nanocrystals upregulate the expression of bone morphogenetic protein-2 and osteopontin genes in mouse smooth muscle cells in vitro. Kidney Int 79: 414-422, 2011.

48. Santos A, Bakker AD, de Blieck-Hogervorst JM, Klein-Nulend J. WNT5A induces osteogenic differentiation of human adipose stem cells via rho-associated kinase ROCK. Cytotherapy 12: 924-932, 2010.

49. Shalhoub V, Shatzen E, Henley C, Boedigheimer M, McNinch J, Manoukian R, Damore M, Fitzpatrick D, Haas K, Twomey B, Kiaei P, Ward S, Lacey DL, Martin D. Calcification inhibitors and Wnt signaling proteins are implicated in bovine artery smooth muscle cell calcification in the presence of phosphate and vitamin D sterols. Calcif Tissue Int 79: 431-442, 2006.

50. Shanahan CM, Crouthamel MH, Kapustin A, Giachelli CM. Arterial calcification in chronic kidney disease: key roles for calcium and phosphate. Circ Res 109: 697-711, 2011. 
51. Shao JS, Pingsterhaus JM, Cheng SL, Charlton-Kachigian N, Loewy AP, Towler DA. Msx2 promotes cardiovascular calcification by activating paracrine Wnt signals. J Clin Invest 115: 1210-1220, 2005.

52. Shtutman M, Zhurinsky J, Simcha I, Albanese C, D'Amico M, Pestell $\mathbf{R}$, Ben-Ze'ev A. The cyclin D1 gene is a target of the $\beta$-catenin/LEF-1 pathway. Proc Natl Acad Sci USA 96: 5522-5527, 1999.

53. Slatopolsky E, Finch J, Ritter C, Takahashi F. Effect of 19-nor$1,25(\mathrm{OH}) 2 \mathrm{D} 2$, a new analogue of calcitriol on secondary hyperparathyroidism in uremic rats. Am J Kidney Dis 32: S40-S47, 1998.

54. Soshnikova N, Zechner D, Huelsken J, Mishina Y, Behringer RR, Taketo MM. Crenshaw Genetic interaction between Wnt/ $\beta$-catenin, and BMP receptor signaling during formation of the AER and the dorsalventral axis in the limb. Genes Dev 17: 1963-1968, 2003.

55. Tang DZ, Hou W, Zhou Q, Zhang M, Holz J, Sheu TJ, Li TF, Cheng SD, Shi Q, Harris SE, Chen D, Wang YJ. Osthole Stimulates Osteoblast Differentiation and Bone Formation by Activation of $\beta$-Catenin-BMP Signaling. J Bone Miner Res 25: 1234-1245, 2010.

56. Tyson KL, Reynolds JL, McNair R, Zhang Q, Weissberg PL, Shanahan CM. Osteo/chondrocytic transcription factors and their target genes exhibit distinct patterns of expression in human arterial calcification. Arterioscler Thromb Vasc Biol 23: 489-494, 2003.

57. Van Gijn ME, Daemen MJ, Smits JF, Blankesteijn WM. The wntfrizzled cascade in cardiovascular disease. Cardiovasc Res 55: 16-24, 2006.
58. Villa-Bellosta R, Millan A, Sorribas V. Role of calcium-phosphate deposition in vascular smooth muscle cell calcification. Am J Physiol Cell Physiol 300: C210-C220, 2011.

59. Wang X, Xiao Y, Mou Y, Zhao Y, Blankesteijn WM, Hall JL. A role for the $\beta$-catenin/T-cell factor signaling cascade in vascular remodeling. Circ Res 90: 340-347, 2002.

60. Williams BO, Insogna KL. Where Wnts went: the exploding field of Lrp5 and Lrp6 signaling in bone. J Bone Miner Res 24: 171-178, 2009.

61. Wilson PWF, Kauppila LI, O'Donnell CJ, Kiel DP, Hannan M, Polak JM, Cupples LA. Abdominal aortic calcific deposits are an important predictor of vascular morbidity and mortality. Circulation 103: 15291534, 2001.

62. Yan D, Wiesmann M, Rohan M, Chan V, Jefferson AB, Guo L, Sakamoto D, Caothien RH, Fuller JH, Reinhard C, Garcia PD, Randazzo FM, Escobedo J, Fantl WJ, Williams LT. Elevated expression of axin 2 and hnkd mRNA provides evidence that Wnt $/ \beta$-catenin signaling is activated in human colon tumors. Proc Natl Acad Sci USA 98: 14973-14978. 2001.

63. Zebger-Gong H, Müller D, Diercke M, Haffner D, Hocher B, Verberckmoes S, Schmidt S, D'Haese PC, Querfeld U. 1,25-Dihydroxyvitamin D3-induced aortic calcifications in experimental uremia: upregulation of osteoblast markers, calcium-transporting proteins and osterix. J Hypertens 29: 339-348, 2011.

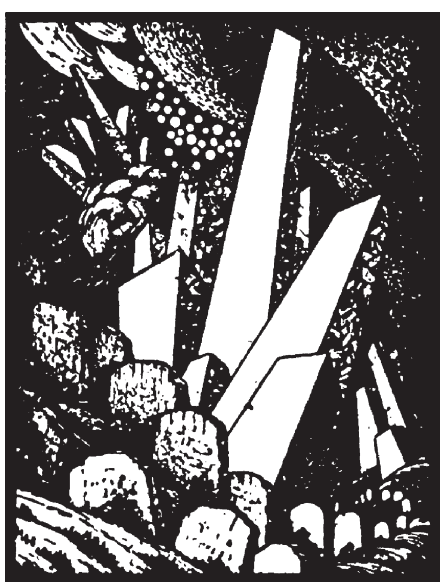

